\section{INHIBITION OF LIPOXYGENASES AND CYCLOOXYGENASES BY Momordica charantia}

\author{
A Rafidah A Mohd Yunosa, Muhammad Helmi Nadria,b, Mohamad \\ Roji Sarmidia,b, Kian-Kai Chenga,b*
}

alnnovation Centre in Agritechnology, Universiti Teknologi Malaysia, 84600 Pagoh, Muar, Johor, Malaysia

bSchool of Chemical \& Energy Engineering, Faculty of Engineering, Universiti Teknologi Malaysia, 81310 UTM Johor Bahru, Johor, Malaysia
Article history

Received

14 January 2020

Received in revised form

29 July 2020

Accepted

9 August 2020

Published online

27 August 2020

*Corresponding author chengkiankai@utm.my

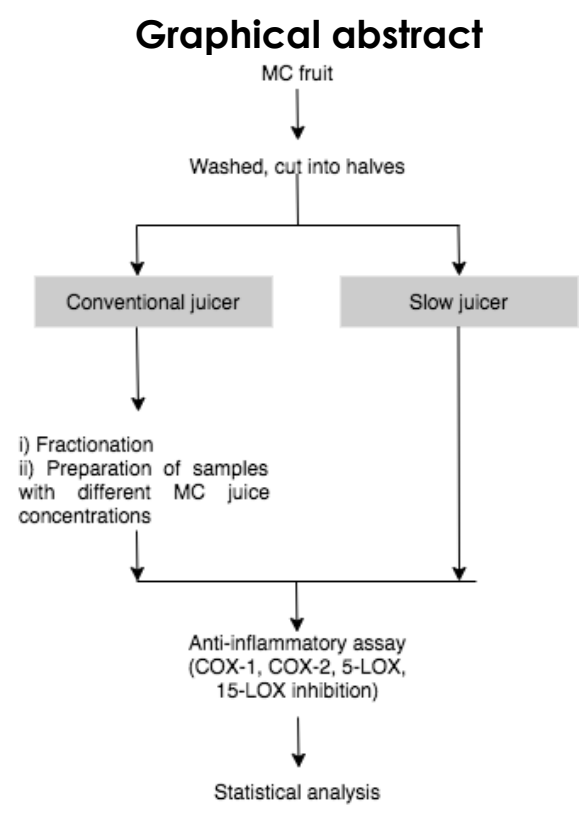

\begin{abstract}
Momordica charantia (MC) is a climber belongs to the Cucurbitaceae family. While there are accumulating evidences showing its pharmacological activities, the effects of fractionation and processing on its anti-inflammatory activity have not been fully elucidated. In this study, we aimed to investigate the antiinflammatory effects of $M C$ raw juice and fractions from $M C$ fruit extract and to evaluate the effect of processing methods on its anti-inflammatory activity. First, MC juice was extracted using a conventional juicer (raw juice) and fractionated using a solid phase extraction method into five fractions; strong acid, weak acid, neutral, weak base, and strong base fractions. The raw juice and its fractions then were tested for their anti-inflammatory activities including cyclooxygenase-1 (COX1). cyclooxygenase-2 (COX-2), 5-lipoxygenase (5-LOX), and 15-lipoxygenase (15LOX) inhibition assays. The results showed that the COX-1 inhibition activity of MC can be attributed to the neutral metabolites (52.60\% inhibition). In contrast, the anti-COX-2 activity of MC was found exerted collectively by metabolites in multiple fractions (strong base, neutral, strong acid fractions). Contrarily, metabolites from all five fractions contributed to the MC inhibition activities on 5 -LOX $155.51 \%$ inhibition for raw juice) and 15-LOX (55.3\% inhibition for raw juice). Additionally, the current findings showed that the juice processing technique influenced the plant bioactivity, where juice extract obtained from slow juicer showed consistently higher anti-inflammatory activities than juice from conventional juicer. In summary, the current study provided evidences of anti-inflammatory action of MC and its fractions, which may contribute towards an improved processing and fractionation strategy.
\end{abstract}

Keywords: Momordica charantia, anti-inflammatory, cyclooxygenase, lipoxygenase

\begin{abstract}
Abstrak
Momordica charantia (MC) merupakan sejenis tumbuhan memanjat daripada keluarga Cucurbitaceae. Biarpun kajian terdahulu telah membuktikan pelbagai aktiviti farmakologi oleh MC, kesan pemecahan dan pemprosesan ke atas aktiviti antiradang masih belum diketahui. Dalam kajian ini, kami menguji kesan kaedah pemprosesan ke atas aktiviti antiradang jus mentah MC dan ekstrak pemecahannya. Jus MC dihasilkan dengan menggunakan alat pemerah jus konvensional (jus mentah). Jus ini seterusnya dipisahkan kepada lima pecahan iaitu pecahan asid kuat, asid lemah, neutral, alkali lemah, alkali kuat, dengan menggunakan kaedah pengekstrakan fasa pepejal. Seterusnya, jus mentah dan pecahannya diuji aktiviti antiradang malalui perencatan enzim cyclooxygenase- 1 (COX-1), cyclooxygenase-2 (COX-2), 5-lipoxygenase (5-LOX), dan 15-lipoxygenase (15-LOX). Keputusan ujikaji menunjukkan bahawa aktiviti perencatan COX-1 oleh
\end{abstract}


MC disumbangkan oleh metabolit neutral (52.60\% perencatan). Sebaliknya, aktiviti perencatan COX-2 oleh MC disumbangkan oleh metabolit daripada tiga pecahan (alkali kuat, neutral, asid kuat) secara kolektif. Manakala kelima-lima pecahan menyumbang kepada perencatan enzim 5-LOX $155.51 \%$ perencatan bagi jus mentah) dan 15-LOX (55.3\% perencatan bagi jus mentah). Tambahan pula, kajian ini menunjukkan bahawa teknik pemprosesan jus mempengaruhi bioaktiviti tumbuhan. Jus yang dihasilkan menggunakan alat pemerah jus perlahan menunjukkan aktiviti antiradang yang lebih tinggi secara konsisten berbanding jus yang dihasilkan menggunakan alat pemerah jus konvensional. Kesimpulannya, kajian ini membuktikan aktiviti antiradang oleh jus MC dan pecahannya yang boleh menyumbang kepada penambahbaikan dalam strategi pemprosesan dan pemecahan untuk MC.

(C) 2020 Penerbit UTM Press. All rights reserved

\subsection{INTRODUCTION}

Inflammation is a condition derived from tissue response to biological, physical and chemical stimulations to eliminate injuring stimuli such as pathogens, irritant and damaged cells [1, 2]. Although inflammation response is important in physiological condition, there are accumulating evidences associating inflammation with diseases including asthma, psoriasis, inflammatory bowel disease, atherosclerosis, insulin resistance, rheumatoid arthritis and cancer [3, 4, 5]. When inflammation occurs, the inflammatory mediators will be released from the activated inflammatory cells (eosinophils, neutrophils, mononuclear phagocytes, macrophages). The released inflammatory mediators are including lipoxygenases (LOX) and cyclooxygenases (COX) enzymes, nitric oxide (NO), prostaglandin E2 (PGE2), cytokines such as tumor necrosis factor (TNF-a) and interleukins (IL), and transcription factor as nuclear factor (NFKB) $[6,7,8]$.

Lipid mediators including prostaglandins, thromboxane, leukotrienes, and lipoxins play important roles in biological activities such as the maintenance of normal hemostasis, blood pressure regulation, renal function, reproduction and host defense [9]. COX is the rate-limiting enzyme and responsible for the production of prostaglandins, prostacyclins, thromboxanes from arachidonic acid [10]. COX has two isoforms; cyclooxygenase-1 (COX1) and cyclooxygenase-2 (COX-2). COX-1 is a housekeeping enzyme that is constitutively expressed in the body and particularly important for gastrointestinal protection. On the other hand, cyclooxygenase-2 (COX-2) is an inducible cyclooxygenase which is enhanced by cytokines, growth factors and other inflammatory ulcerogenic stimuli [11]. The induction of COX-2 is responsible for the pathological process of several inflammatory conditions including rheumatoid arthritis, cancer, respiratory disorders and Alzheimer's disease [10].

Lipoxygenases (LOX) are oxidative enzymes which play a major role in the regulation of inflammatory responses [12]. The LOX reactions are catalyzed by nonheme iron-containing dioxygenases, which involved the insertion of oxygen into polyunsaturated fatty acids such as arachidonic acid and linoleic acid with one or more cis,cis-1,4-penta-diene moieties in the structure [9, 12]. LOX catalyzed the hydroperoxy eicosatetraenoic acids (HPETEs) formation from arachidonic acid which the HPETEs are subsequently reduced and transformed to form eicosanoids, which are the signaling molecules that plays vital role in the immune responses and other physiological processes [12]. Generally, the LOX can be classified as 5-, 8-, 12-, and 15-LOX depending to the selectivity to oxygenate fatty acids in specific position [12]. Leukotrienes, the metabolic products through 5-LOX activation are responsible in initiating immune cell chemotaxis and actively contributing in inflammatory occurrence such as asthma, allergy, bowel diseases, cancers, cardiovascular diseases (atherosclerosis, heart attack, stroke) [13, 14, 15]. To date, inflammation is typically treated with several anti-inflammatory drugs, which include nonsteroidal anti-inflammatory drugs (NSAIDs), glucocorticoids, and immunosuppressant drugs. However, many of the drugs are found to be insufficiently effective and may lead to unwanted side effects [16]. There is an increasing interest to search for plant-derived antiinflammatory compounds which may have several advantages than synthetic compounds due to less toxicity, more accessibility and less expensive [17].

Momordica charantia Linn. (MC) or bitter gourd belongs to Cucurbitaceae family. The fruit contains bitter, cucurbitane-type triterpenoids, including charantin, cucurbitacins and momordicins [18, 19]. The seeds, fruit and leaves of MC had shown a wide range of pharmacological activities, and $M C$ has been traditionally used for its therapeutic activities including anti-diabetic, anti-inflammatory, hypocholesterolemic, hypotriglyceridemic, antitumor, hypo-tensive, immunostimulant, anti-viral, antiinflammatory, anti-oxidant, anti-leukemic, antimicrobial, anthelmintic, anti-mutagenic, anti-ulcer, and insecticidal properties $[20,21,22] . M C$ is particularly known for its hypoglycemic activity which leads to reduction in blood glucose level in Type 2 diabetic patients [23, 24] and animal disease models $[25,26]$. In addition to its anti-diabetic activity, $M C$ is also recognized as an anti-inflammatory agent. Several reports had consistently shown its anti- 
inflammatory activities; Chao and colleagues reported that adding wild $M C$ to diets of sepsisinduced mice inhibited the NF-KB, iNOS and COX-2 expressions, leading to improvement of the inflammation responses [27]. A study by Bao and colleagues showed that freeze-dried $M C$ fruit reduced the adipose tissue inflammation in dietinduced obese mice where the pro-inflammatory cytokine MCP-1 expression was depressed in epicardial adipose tissue and brown adipose tissue. Furthermore, the IL-6 and TNF-a expression in epicardial adipose tissue were also reduced [28]. Another recent study by Dwijayanti and collegues found out that the expression of interleukin-1 $\beta$ mRNA and hepatic lipid accumulation in hepatocytes had been reduced in ob/ob mice type 2 diabetes mellitus model after 7 days of administration with ethyl acetate soluble fraction from MC fruit [18]. In addition, a previous study that involved MC-treated rat model showed that the levels of pro-inflammatory cytokines in the liver, muscle and epididymal fats were significantly down-regulated. Moreover, the activation of NF-KB in the liver and muscle was decreased in MC-treated rat group compared to the non-treated group [29]. These accumulating evidences support MC as a potent anti-inflammatory agent.

Previously, a number of studies had been carried out on solvent fractionation of $M C[30,31,32]$. However, fractionation of $M C$ based on ionic exchange for the recovery of acidic, neutral and basic components from MC, and anti-inflammatory effects of the resulting fractions have yet to be elucidated. It is known that natural products consist of acid-base character which enables compounds to be selectively isolated based on the functional groups through $\mathrm{pH}$ manipulation in the fractionation protocol [33]. The fractionation strategy may provide new insight into the anti-inflammatory activities of metabolites in MC. The MC sample used in antiinflammatory studies is commonly processed through freeze-drying prior to further extraction [31, 32, 34]. While in daily life, consumers of MC usually produce MC fruit juice by using common home appliances such as the sharp-blade conventional juicer or slow juicer. Therefore, a study on the effect of processing methods will be useful for the production of functional beverage of $M C$ with high antiinflammatory activity. Taken together, a study on fractionation and processing of MC may provide a novel understanding of their effects on antiinflammatory activities of MC.

\subsection{METHODOLOGY}

\section{Chemicals and Kits}

Strata $^{\mathrm{TM}} \mathrm{X}$ Polymeric Reversed Phase Strata-X-AW and Strata-X-CW were purchased from Phenomenex, Torrance, California. Lipoxygenase Inhibitor Screening
Assay Kit (Item no.: 760700), Lipoxygenase (potato) Screening Enzyme (Item no.: 60401) and COX Colorimetric Inhibitor Screening Assay Kit (Item no.: 701050) were purchased from Cayman Chemical, Ann Arbor, MI, USA.

\section{Plant Material and Preparation of MC Juice}

Fresh unripe MC was purchased from local wholesaler in Pagoh, Muar, Johor, Malaysia. The raw material was processed using either a conventional juicer or a slow juicer. $5 \mathrm{~kg}$ of $\mathrm{MC}$ were used to obtain juice using the conventional juicer while for slow juicer, $4 \mathrm{~kg}$ of MC were used. No solvent or water were added during the juice processing. Briefly, the MC fruits were washed, sliced and extracted using a conventional fruit juicer (Kenal EX-362, Malaysia). The produced juice was then centrifuged (Kubota 7000, Japan) at $9,000 \mathrm{rpm}, 4{ }^{\circ} \mathrm{C}$ for 15 minutes. The supernatant was collected and stored at $-20^{\circ} \mathrm{C}$ until further use. In addition, MC fruits were processed using a slow juicer (Hurom, H-AA Series, Korea), centrifuged and stored at $-20{ }^{\circ} \mathrm{C}$ until further process. To study the effect of $M C$ raw juice in different concentration on anti-inflammatory activities, four different concentrations were prepared ranging $25 \%$, $50 \%, 75 \%$ and $100 \%$.

\section{Fractionation of MC Raw Juice using Solid-phase Extraction Method}

For this section, solid-phase extraction (SPE) method was used to obtain MC fraction. The Strata-X, Strata$\mathrm{X}-\mathrm{AW}$ and Strata-X-CW cartridges (Phenomenex, CA, USA) were used for fractionation, by which a reversed phase functionalized polymeric sorbent provides strong retention of either neutral, acidic or basic compounds under aggressive, high organic wash conditions. Each cartridge served different purpose of collecting fractions which Strata- $X$ was used to obtain neutral fractions, Strata-X-AW for acidic fractions and Strata-X-CW for basic fractions. The fractionation protocol for these cartridges involved conditioning, equilibrating, sample loading, washing and eluting steps. The fractionation process for each cartridge was presented in Figure 1.

All purchased cartridges size was standardized to $100 \mathrm{mg} / 6 \mathrm{ml}$ which means $100 \mathrm{mg}$ sorbent mass and $6 \mathrm{ml}$ was the volume of the cartridge per load. Each cartridge permitted up to $25 \mathrm{ml}$ of sample to permeate the sorbent for single experiment. Prior the fractionation process, a collection bottle was placed inside the vacuum manifold. Then, the removable cover was placed, and the cartridge was installed on top of the manifold carefully. The stopcock was in lock position to avoid uncontrollable solvent drop. Once the setup was ready, the vacuum pump was turn on and the cartridge was initially conditioned with $3 \mathrm{ml}$ of methanol. The stopcock was adjusted slowly to allow methanol to pass through the sorbent. The flow rate was adjusted at 1 drop/second. After the methanol fully pas through the sorbent, the 
cartridge then was equilibrated with $3 \mathrm{ml}$ of distilled water.

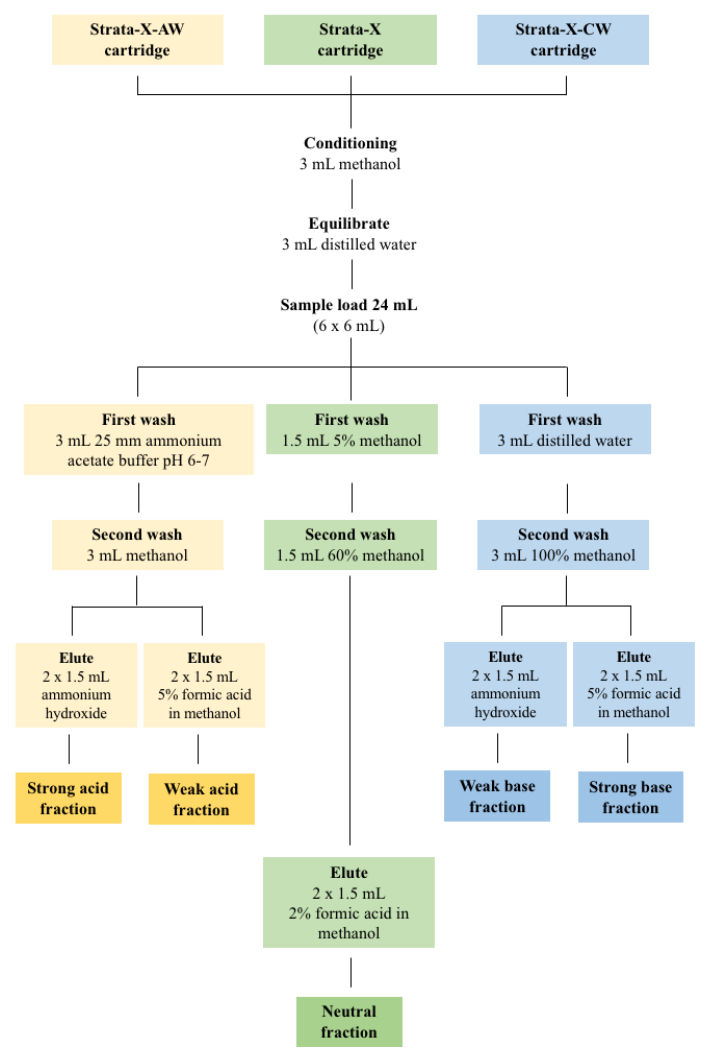

Figure 1 Fractionation protocol using cartridge

\section{Anti-inflammatory Study of MC Juice and Its Fractions}

For cyclooxygenase essay, the activity was carried out according to instructions provided by the manufacturer. COX Colorimetric Inhibitor Screening Assay Kit (Cayman's Chemical) measures the peroxidase component of COXs, oxidized N,N,N',N'tetramethyl-p-phenylenediamine (TMPD). The oxidized TMPD can be assayed colorimetrically and detected at $590 \mathrm{~nm}$ wavelength. The kit provides two enzymes; COX-1 (ovine) and COX-2 (human recombinant), for screening the isomer enzymespecific inhibitors which provides convenience to screen multi-inhibitors simultaneously. Each well final volume was $220 \mu \mathrm{l}$. All buffer, enzymes, inhibitors, substrates were prepared prior performing the assay protocol. In background wells, $160 \mu$ lassay buffer, 10 $\mu \mathrm{l}$ heme and $10 \mu \mathrm{l}$ methanol were added to three wells. In initial activity wells, $150 \mu \mathrm{L}$ assay buffer, $10 \mu \mathrm{l}$ heme, $10 \mu$ l enzyme and $10 \mu$ methanol were added to three wells. In sample inhibitor wells, $150 \mu$ assay buffer, $10 \mu \mathrm{l}$ heme and $10 \mu \mathrm{l}$ enzyme and $10 \mu \mathrm{l}$ sample were added. Blank for each sample was prepared separately by mixing $90 \mu$ assay buffer with $10 \mu \mathrm{l}$ sample. The plate was placed on a shaker for thirty seconds and incubated at room temperature for five minutes. Next, $20 \mu$ colorimetric substrate followed by $20 \mu \mathrm{l}$ arachidonic acid was added to all wells. The plate was carefully shake for 30 seconds and incubated at room temperature for 2 minutes. The plate was read at 590 (Versamax ELISA, Molecular Devices, CA, USA). The pipetting components are presented in Table 1. The results were presented in percentage of inhibitions which was calculated using equation 1.

$\%$ Inhibition $=\left[\frac{A b s_{\text {initial activity }}-A b s_{\text {sample }}}{A b s_{\text {initial activity }}}\right] \times 10 q_{\text {Eq. 1) }}$

Table 1 COXs inhibition assay pipetting components

\begin{tabular}{lcccc}
\hline Well/Solution & $\begin{array}{c}\text { Backgrou } \\
\text { nd }(\boldsymbol{\mu l})\end{array}$ & $\begin{array}{c}\text { Initial } \\
\text { activi } \\
\text { ty }(\boldsymbol{\mu l})\end{array}$ & $\begin{array}{c}\text { Sampl } \\
\mathbf{e} \\
\text { blank } \\
(\boldsymbol{\mu l})\end{array}$ & $\begin{array}{c}\text { Inhibito } \\
\mathbf{r}(\mathbf{M C} \\
\text { sample } \\
\mathbf{s})(\boldsymbol{\mu l})\end{array}$ \\
\hline Assay buffer & 160 & 150 & 160 & 150 \\
Heme & 10 & 10 & 10 & 10 \\
COX enzymes & - & 10 & - & 10 \\
$\begin{array}{l}\text { Methanol } \\
\text { Sample }\end{array}$ & 10 & 10 & - & - \\
Colorimetric & - & - & 10 & 10 \\
substance & 20 & 20 & 20 & 20 \\
Arachidonic acid & 20 & 20 & 20 & 20 \\
\hline
\end{tabular}

Total volume for each well: $220 \mu$

For lipoxygenase essay, the activity was carried out according to instructions provided by the manufacturer. Lipoxygenase Inhibitor Screening Assay Kit (Cayman's Chemical) quantify the hydroperoxides product from lipoxygenation process using the purified lipoxygenases enzyme. The detection reaction is equally sensitive to hydroperoxides at fatty acid position at any carbon length. Hence, it is a general detection method for LOXs and useful to screen variety of potential LOXs inhibitor compounds. To start the process, all buffer, enzymes, inhibitors, substrates were prepared and diluted according to the protocol. Blanks were prepared for each sample respectively. In this experiment, 5-LOX assay used linoleic acid as substrate while 15-LOX assay used arachidonic acid which performed in a two separate 96-wellplate. In blank wells, $100 \mu$ lassay buffer was added into three wells. In positive control wells, $90 \mu \mathrm{l}$ enzyme and $10 \mu \mathrm{l}$ assay buffer were added to three wells. In 100\% Initial activity wells, $90 \mu$ l enzyme and $10 \mu$ methanol were added to three wells. In standard inhibitor wells, $90 \mu \mathrm{l}$ enzyme and $10 \mu \mathrm{l}$ nordihydroguaiaretic acid (NDGA) were added into three wells. In Sample Inhibitor Well, $90 \mu \mathrm{l}$ enzyme and $10 \mu \mathrm{l}$ sample were added to three wells. Blank sample was provided for each sample by mixing $90 \mu$ assay buffer with $10 \mu$ sample. The plate was incubated at room temperature for five minutes. Next, $10 \mu$ substrate was added to all wells. This is where the initiation process begins. The plate was placed on a shaker for 10 minutes. $100 \mu$ chromogen 
was added to each well to stop the process. The plate was placed on the shaker for another five minutes to develop colour reaction. Then, the plate was read at $495 \mathrm{~nm}$ (Versamax ELISA, Molecular Devices, CA, USA). The pipetting components are presented in Table 2. The results were presented in percentage of inhibitions which was calculated using Equation 1.

Table 2 LOXs inhibition assay pipetting components

\begin{tabular}{|c|c|c|c|c|c|c|}
\hline $\begin{array}{l}\text { Well/Solutio } \\
n\end{array}$ & $\begin{array}{l}\text { Blan } \\
\mathrm{k}(\mu \mathrm{l})\end{array}$ & $\begin{array}{l}\text { Positi } \\
\text { ve } \\
\text { contr } \\
\text { ol } \\
(\mu \mathrm{l})\end{array}$ & $\begin{array}{c}100 \% \\
\text { initial } \\
\text { activ } \\
\text { ity } \\
(\mu \mathrm{l})\end{array}$ & $\begin{array}{c}\text { Inhib } \\
\text { itor } \\
\text { (ND } \\
\text { GA) } \\
(\mu l)\end{array}$ & $\begin{array}{c}\text { Inhib } \\
\text { itor } \\
\text { (MC } \\
\text { Sam } \\
\text { ples) } \\
(\mu \mathrm{l})\end{array}$ & $\begin{array}{l}\text { Sam } \\
\text { ple's } \\
\text { blan } \\
k(\mu l)\end{array}$ \\
\hline $\begin{array}{l}\text { Assay } \\
\text { buffer }\end{array}$ & 100 & 10 & - & - & - & 90 \\
\hline $\begin{array}{l}\text { LOX } \\
\text { enzyme }\end{array}$ & - & 90 & 90 & 90 & 90 & - \\
\hline Methanol & - & - & 10 & - & - & - \\
\hline Inhibitor & - & - & - & $10^{*}$ & 10 & $10^{* *}$ \\
\hline $\begin{array}{l}\text { Arachidoni } \\
\text { c acid }\end{array}$ & 10 & 10 & 10 & 10 & 10 & 10 \\
\hline $\begin{array}{l}\text { Chromoge } \\
\mathrm{n}\end{array}$ & 100 & 100 & 100 & 100 & 100 & 100 \\
\hline
\end{tabular}

\section{Data Analysis}

The results of anti-inflammatory study were shown as bar graph and the error bars represent standard deviation (SD). All experiments were performed in triplicates. The data were analysed using the Student's t-test, ANOVA followed by Dunnett's posthoc test. Comparison with $\mathrm{p}<0.05$ is considered significant.

\subsection{RESULTS AND DISCUSSION}

\section{Cyclooxygenases (COXs) Inhibition Activity}

Cyclooxygenases are an essential enzyme that are responsible for the conversion of arachidonic acid, a polyunsaturated fatty acid to prostaglandins (PGs), an inflammatory mediator [35]. There are two COX isomers; COX-1 which plays an essential role in homeostasis and gastrointestinal protection; COX-2, an inducible COX which enhanced by cytokines and is involved in the development of inflammatory events [11].

Effect of MC Raw Juice and Fractions on COXs inhibition Activity

This study investigated the effect of $M C$ fractions against COXs. The juice was initially loaded into the cartridge (Strata-X for Neutral, Strata-X-AW for Acid, Strata-X-CW for Base) and further fractionated separately to five different fractions namely strong acid, weak acid, neutral, weak base and strong base fractions. Then, the MC Raw Juice and its fractions were tested against COXs inhibition. The data is presented in Figure 2.

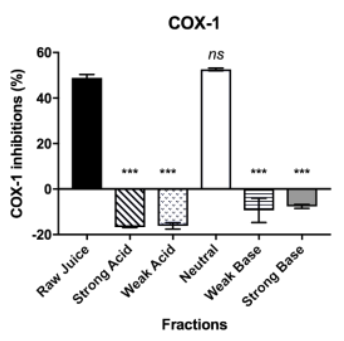

(a)

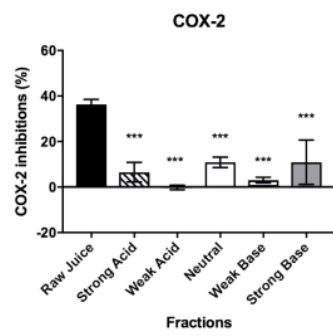

(b)
Figure 2 Effect of MC raw juice and fractions on (a) COX-1, (b) COX-2. ${ }^{* * *} \mathrm{p}<0.001$ was obtained from ANOVA with Dunnett's post-hoc test comparing data with raw juice $(n=3)$; ns - not significant

As presented in Figure $2 a$, the neutral fraction and the MC raw juice showed high COX-1 inhibition at $52.60 \%$ and $48.89 \%$, respectively. There was no significant between neutral and raw juice, suggesting that the COX-1 inhibitory action of $M C$ can be attributed to the neutral metabolites. Negative inhibitions were observed for strong base $(-7.66 \%)$, weak base (-9.36\%), weak acid (-16.15\%) and strong acid $(-16.67 \%)$ fractions. In contrast, multiple fractions showed inhibitory effects for COX-2 inhibition (Figure $2 b)$ : raw juice $(36.31 \%)$, strong base $(10.91 \%)$, neutral $(10.87 \%)$, strong acid $(6.52 \%)$, and weak base (3.07\%). As a summary, MC showed inhibitory effects on both COX-1 and COX-2. The anti-COX-1 effect was mainly due to metabolites in the neutral fraction, while the anti-COX-2 activity of MC was exerted collectively by metabolites in multiple fractions.

Effect of Processing Method on COXs Inhibition Activity

In this section, the effect of processing method on COXs inhibition was investigated. In this study, MC samples were prepared separately through a conventional juicer or a slow juicer. The conventional juicer used sharp-flat blades to reduce the size of sample and separate the juice from the pulp through high-speed centrifugal force. On the other hand, slow juicer used pressing force to extract the juice out through filter with minimal heat and friction. However, the juice extraction rate is relatively slow for a slow juicer compared to a conventional juicer [36]. The COXs inhibition of MC samples produced from different processing methods is presented in Figure 3. 


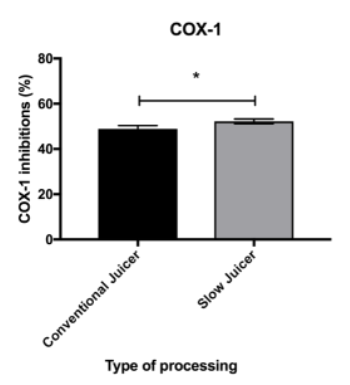

(a)

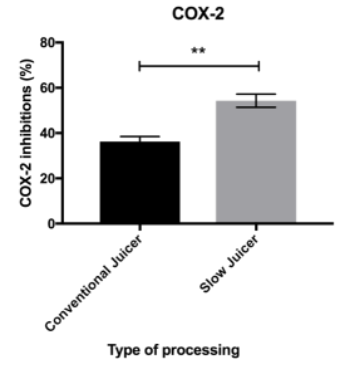

(b)
Figure 3 Effect of processing methods on (a) COX-1, (b) COX-2. ${ }^{*} p<0.05$ and ${ }^{* *} p<0.01$ were obtained from the Student's t-test $(n=3)$

For COX-1 inhibitory study, the MC sample produced by the slow juicer gave the highest inhibition (52.25\%), followed by conventional juicer (47.23\%). A similar order was also found for COX-2 inhibitions where slow juicer showed highest inhibition (54.27\%), followed by conventional juicer (36.31\%). The current results showed that slow juicer is the preferred method for MC juice preparation. This finding is comparable to previous studies by Kim et al. (2015) and Lee et al. (2013) and where both studies reported that slow juicer can retain more phytochemicals compared to conventional juicer $[36,37]$.

A juicer provides a convenient option for the consumer to produce fresh juice from fruits and vegetables. However, nutrient level in the fruits and vegetables can be reduced along the juicing process and lead to destructions of polyphenols and flavonoids [36, 37]. Furthermore, different processing/extraction technique may produce juice with varying amounts of phytochemicals depending on the type of juicer used [38]. In commercial juice industry, pressing methods used may alter the taste of the juice. Notably, high extraction pressure (hard squeeze) produces higher yields. However, a low extraction pressure (soft squeeze) produced less yields but the juice flavor will be more similar to the juice produced by hand manually [39].

Effect of MC Juice Concentrations on COXs Inhibition Activity

The COXs inhibition of MC juice in different concentration was assessed by measuring the peroxidase components of COX. Four different juice concentrations ranging $25 \%, 50 \%, 75 \%$ and $100 \%$ were tested in the current study. From Figure 4, the percentage of COX-1 inhibition showed positive correlation with concentration of $\mathrm{MC}$, increasing from $15.24 \%$ inhibition (25\% MC) to $50.56 \%$ inhibition (75\% MC). There was no significant difference in COX-1 inhibition between the $75 \%$ and $100 \%$ MC samples, indicating that $75 \%$ concentration of $M C$ sample was adequate to exert maximum COX-1 inhibition. On the other hand, samples with $25 \%, 50 \%$ and $100 \%$ concentrations showed no significant difference in percentage of COX-2 inhibition, suggesting that at lower concentrations, $M C$ juice contained more potent COX-2 inhibitors than COX-1 inhibitors. As a summary, the COX-1 inhibitory effect of $M C$ juice increased with increasing concentration in general, while COX-2 inhibition ability of $M C$ juice is more consistent for samples with 25\%-100\% concentration.

A previous study demonstrated that adding $M C$ at the different doses ranging from $1 \%$ to $10 \%$ in sepsis-induced mouse model diets significantly reduced the formation of PGE2, an inflammatory mediator by reducing the expression of COX-2. The study also found that MC significantly inhibited the expression of other inflammation protein including iNOS, and NF-KB using the same mouse model [40].

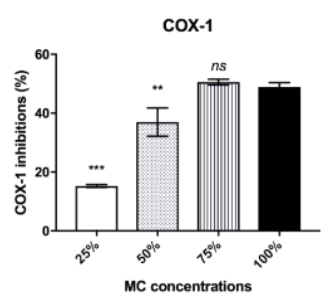

(a)

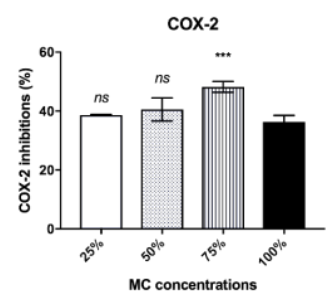

(b)
Figure 4 Inhibitory effect of $M C$ juice concentration on (a) COX-1, (b) COX-2. ** $p<0.01$ and ${ }^{* * *} p<0.001$ were obtained from ANOVA with Dunnett's post-hoc test comparing data with $100 \%$ MC juice concentration as controls $(n=3)$; $n s$ - not significant

\section{Lipoxygenase (LOXs) Inhibition}

The over-expression of lipoxygenases and their leukotrienes product resulted in inflammation events including asthma, atherosclerosis, rheumatoid arthritis, inflammatory bowel diseases, dermatitis, and cancer [12]. A previous research that used obese high-fat-diet-fed mice model demonstrated that leukotrienes B4 (LTB4) was over-expressed in insulin target tissue particularly muscle, liver and adipose tissue. This events directly caused the reduction of insulin sensitivity in hepatocytes and myocytes thus providing a new mechanism connecting inflammation and impaired insulin sensitivity [5]. The present study investigated the potential inhibitory effect of MC on LOXs using Lipoxygenase Inhibitor Screening Assay Kit. The kit detects hydroperoxides produced through lipoxygenation reaction and the absorbance read at $495 \mathrm{~nm}$. The 15-LOX enzyme from soybean is able to catalyze the reactions with both arachidonic acid and linoleic acid as substrate provided with the kit, while 5-LOX enzyme exhibits higher reaction with linoleic acid as substrate. 
Effect of MC Raw Juice and Fractions on LOXs Inhibition Activity

This study investigated the effect of different $M C$ fractions on the activities of LOXs. The MC raw juice and its fractions (strong acid, weak acid, neutral, weak base, strong base) were all tested for their potential 5-LOX and 15-LOX inhibitions. Figure 5a presented the 5-LOX inhibition data. The raw juice performed the highest 5-LOX inhibition at 55.51\%. The inhibitory effects of $M C$ fractions are as followed (in descending order): strong base (13.93\%), strong acid (13.26\%), neutral (9.12\%), weak acid (5.49\%) and weak base $(4.36 \%)$ fractions. As for 15 -LOX, the raw juice resulted in the highest inhibitions at $55.30 \%$ followed by strong base (47.23\%), weak base (42.00\%), strong acid (39.20\%), weak acid (21.28\%) and neutral (14.64\%) fractions (Figure 5b).

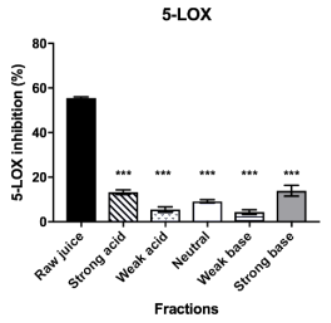

(a)

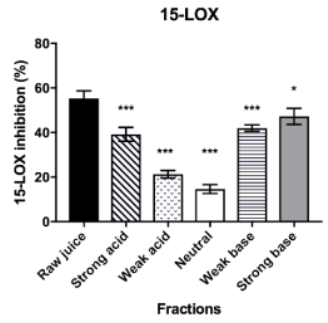

(b)
Figure 5 Effect of MC Raw Juice and Fractions on (a) LOX-1, (b) LOX-2. ${ }^{*} \mathrm{p}<0.05$ and ${ }^{* * *} \mathrm{p}<0.001$ were obtained from ANOVA with Dunnett's post-hoc test comparing data with raw juice $(n=3)$

Based on these results, raw juice provided the highest 5-LOX and 15-LOX inhibition activity than other fractions. However, the raw juice and the fractions inhibition patterns on both LOXs were slightly different. For 5-LOX, it can be seen that all five fractions showed additive inhibitory effect, and the sum of inhibition exerted by all fractions was almost equal to the percentage of inhibition exerted by the raw juice. For 15-LOX inhibition study, MC fractions gave relatively high inhibitory effect (14.64\%-47.23\%), and the metabolites from different fractions may interact to give a $55.30 \%$ inhibition when the enzyme was treated with the raw juice.

Effect of Processing Method on LOXs Inhibition Activity

This section focuses on the effect of different processing methods (namely conventional juicer and slow juicer) on inhibition of LOXs. Comparable with results on inhibition of COXs, samples from slow juicer consistently showed higher inhibitory effects on LOXs, as compared with conventional juicer (Figure 6).

For 5-LOX inhibition study, the data showed that sample produced by the slow juicer gave higher inhibitory effect $(76.46 \%)$ than the conventional juicer
(55.51\%). A same order was found for 15-LOX where juice from slow juicer gave higher inhibition (97.72\%) than the conventional juicer (55.30\%). This finding showed that the juice processing technique influenced the bioactivity of the plant. The phytochemical levels in fruit juice are solely depend on the fruit species, germination, the degree of ripeness and seasonal variation. Different postharvest techniques including storage conditions and processing methods also may affect the phytochemical level in the juice [41]. A previous study suggested that juice extraction techniques by blending and juicing of several kernel fruit (apple, mandarin orange, persimmon and pear) had a significant influence on the phytochemicals and antioxidant property of fruit juices. The researchers also suggest that blending fruit juice that has the highest pulp content may contribute to the higher antioxidant level of the fruit juice [42].

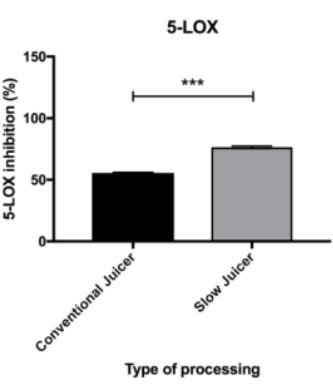

(a)

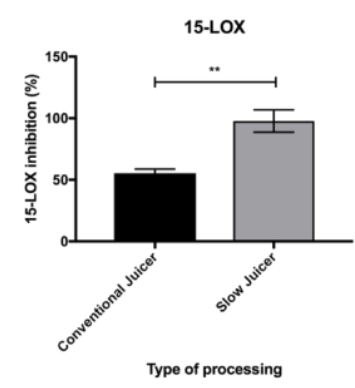

(b)
Figure 6 Effect of processing methods on (a) 5-LOX, (b) 15LOX. ${ }^{* *} \quad \mathrm{p}<0.01$ and ${ }^{* * *} \mathrm{p}<0.001$ were obtained from Student's t-test $(n=3)$

Effect of MC Juice Concentrations on LOXs Inhibition Activity

Next, we assessed the LOXs inhibition by MC samples with different $M C$ concentration ranging from $25 \%$, $50 \%, 75 \%$ to $100 \%$. The MC juice obtained from conventional juicer was used in this experiment. The percent of LOXs inhibition was found to have positive correlation with the concentrations of $M C$ juice (Figure 7). For 5-LOX inhibition study, the highest inhibition was achieved by $100 \%$ MC juice $155.51 \%$ inhibition), followed by $75 \%$ MC juice (44.56\%), $50 \%$ MC juice (27.84\%) and $25 \%$ MC juice (12.43\%). The same order was also found for 15-LOX inhibition, with the percentage of inhibition increased from $4.46 \%$ (25\% MC juice) to $55.30 \%$ (100\% MC juice). 


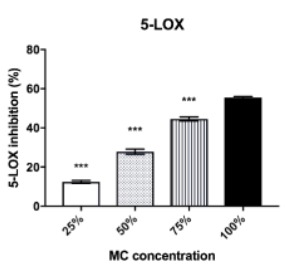

a)

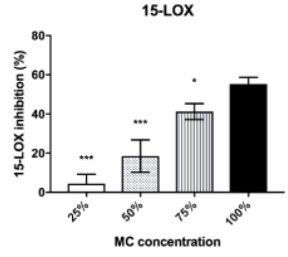

(b)
Figure 7 Effect of $M C$ juice concentration on: (a) 5-LOX, (b) 15-LOX. ${ }^{*} \mathrm{p}<0.05$ and ${ }^{* * *} \mathrm{p}<0.001$ were obtained from ANOVA with Dunnett's post-hoc test comparing data with $100 \%$ MC juice concentration as the controls $(n=3)$

\subsection{CONCLUSION}

The current study focused on the effects of fractionation and processing methods on the inflammatory effects of MC. MC was found to have anti-inflammatory effects on COX-1, COX-2, 5-LOX and 15-LOX activities. Notably, study on the MC fractions showed that the anti COX-1 activity of MC can be solely attributed to neutral metabolites, and selective COX-2 inhibitors may be present in both strong acid and strong base fractions. On the other hand, MC raw juice exerted about $55 \%$ inhibitions on both 5-LOX and 15-LOX, but all five fractions contributed collectively to its LOXs inhibitory effect.

In this study, MC juice produced using a slow juicer consistently showed higher inhibitions on COX1, COX-2,5-LOX and 15-LOX activities, as compared with juice obtained from conventional juicer. The results supported previous findings that slow juicer can retain bioactivities of food product better than a conventional juicer. This may be due to heat generated by the high-speed blades in a conventional juicer that caused nutrient degradation. Taken together, slow juicer was found to be the preferred method for juicing to preserve anti-inflammatory bio-compounds. Collectively, the current results may offer useful strategy for improved processing and fractionation of MC.

\section{Acknowledgement}

We greatly acknowledge financial support from Universiti Teknologi Malaysia through Research University Grant (Q.J130000.2546.14H62 and Q.J130000.2509.18H73).

\section{References}

[1] Hadagali, M. D. and Chua, L. S. 2014. The Antiinflammatory and Wound Healing Properties of Honey. European Food Research and Technology. 239(6): 10031014.

[2] Verdam, M. C. S., Guilhon-Simplicio, F., Barbosa, G. S., Magalhães, A. L., Oliveira, C. I., Almeida, P., Machado, T.
M., Vasconcellos, M. C., Lima, E. S., Ohana, D. T. and Pereira, M. M. 2015. Anti-inflammatory Action of Justicia acuminatissima Leaves. Revista Brasileira de Farmacognosia. 25(3): 264-268.

[3] Libby, P. 2006. Inflammation and Cardiovascular Disease Mechanisms. The American Journal of Clinical Nutrition. 83(2): 456S-460S.

[4] Solinas, G., Marchesi, F., Garlanda, C., Mantovani, A. and Allavena, P. 2010. Inflammation-mediated Promotion of Invasion and Metastasis. Cancer and Metastasis Reviews. 29(2): 243-248.

[5] Li, P., Bandyopadhyay, G., Lagakos, W.S., Talukdar, S., Osborn, O., Johnson, A., Chung, H., Mayoral, R., Maris, M., Ofrecio, J. M. and Taguchi, S. 2015. LTB4 Promotes Insulin Resistance in Obese Mice by Acting on Macrophages, Hepatocytes and Myocytes. Nature Medicine. 21 (3): 239247.

[6] Ibrahim, S. R., Mohamed, G. A., Alshali, K. Z., Haidari, R. A. A., El-Kholy, A. A. and Zayed, M. F. 2018. Lipoxygenase Inhibitors Flavonoids from Cyperus rotundus Aerial Parts. Revista Brasileira de Farmacognosia. 28(3): 320-324.

[7] Al-Attas, A. A., El-Shaer, N. S., Mohamed, G. A., Ibrahim, S. R. and Esmat, A. 2015. Anti-inflammatory Sesquiterpenes from Costus Speciosus Rhizomes. Journal of Ethnopharmacology.176: 365-374.

[8] Nguyen, T. Y., To, D. C., Tran, M. H., Lee, J. S., Lee, J. H., Kim, J. A., Woo, M. H. and Min, B. S. 2015. Antiinflammatory Flavonoids Isolated from Passiflora foetida. Natural Product Communications. 10(6): $1934578 \times 1501000634$.

[9] Haeggström, J. Z. and Funk, C. D. 201 1. Lipoxygenase and Leukotriene Pathways: Biochemistry, Biology, and Roles in Disease. Chemical Reviews. 111 (10): 5866-5898.

[10] Rumzhum, N. N. and Ammit, A. J. 2016. Cyclooxygenase 2: Its Regulation, Role and Impact in Airway Inflammation. Clinical \& Experimental Allergy. 46(3): 397-410.

[11] Hawkey, C. J. 2001. COX-1 and COX-2 Inhibitors. Best Practice \& Research Clinical Gastroenterology. 15(5): 801820.

[12] Wisastra, R. and Dekker, F. J. 2014. Inflammation, Cancer and Oxidative Lipoxygenase Activity are Intimately Linked. Cancers. 6(3): 1500-1521.

[13] Joshi, Y. B. and Praticò, D. 2015. The 5-lipoxygenase Pathway: Oxidative and Inflammatory Contributions to the Alzheimer's Disease Phenotype. Frontiers in Cellular Neuroscience. 8: 436.

[14] Chung, L. Y., Soo, W. K., Chan, K. Y., Mustafa, M. R., Goh, S. H. and Imiyabir, Z. 2009. Lipoxygenase Inhibiting Activity of Some Malaysian Plants. Pharmaceutical Biology. 47(12): $1142-1148$.

[15] Kanaoka, Y. and Boyce, J. A. 2014. Cysteinyl Leukotrienes and Their Receptors; Emerging Concepts. Allergy, Asthma \& Immunology Research. 6(4): 288-295.

[16] Fürst, R. and Zündorf, I. 2015. Plant-derived Antiinflammatory Compounds: Hopes and Disappointments Regarding the Translation of Preclinical Knowledge into Clinical Progress. Mediators of inflammation. 2014.

[17] Iftikhar, H. and Rashid, S., 2014. Molecular Docking Studies of Flavonoids for Their Inhibition Pattern against $\beta$-catenin and Pharmacophore Model Generation from Experimentally Known Flavonoids to Fabricate More Potent Inhibitors for Wnt Signaling Pathway. Pharmacognosy Magazine. 10(Suppl 2): \$264.

[18] Dwijayanti, D. R., Shimada, T., Ishii, T., Okuyama, T., Ikeya, Y., Mukai, E. and Nishizawa, M. 2020. Bitter Melon Fruit Extract Has a Hypoglycemic Effect and Reduces Hepatic Lipid Accumulation in ob/ob Mice. Phytotherapy Research. 34(6): 1338-1346.

[19] Tan, S. P., Kha, T. C., Parks, S. E. and Roach, P. D. 2016. Bitter Melon (Momordica charantia L.) Bioactive Composition and Health Benefits: A Review. Food Reviews International. 32(2): 181-202. 
[20] Grover, J. K. and Yadav, S. P. 2004. Pharmacological Actions and Potential Uses of Momordica Charantia: A Review. Journal of Ethnopharmacology. 93(1): 123-132.

[21] Tan, H. F. and Gan, C. Y. 2016. Polysaccharide with Antioxidant, a-amylase Inhibitory and ACE Inhibitory Activities from Momordica charantia. International Journal of Biological Macromolecules. 85: 487-496.

[22] Li, Z., Xia, A., Li, S., Yang, G., Jin, W., Zhang, M. and Wang, S. 2020. The Pharmacological Properties and Therapeutic Use of Bitter Melon (Momordica charantia L.). Current Pharmacology Reports. 1-7.

[23] Fuangchan, A., Sonthisombat, P., Seubnukarn, T., Chanouan, R., Chotchaisuwat, P., Sirigulsatien, V., Ingkaninan, K., Plianbangchang, P. and Haines, S. T. 2011. Hypoglycemic Effect of Bitter Melon Compared with Metformin in Newly Diagnosed Type 2 Diabetes Patients. Journal of Ethnopharmacology. 134(2): 422-428.

[24] Hasan, I. and Khatoon, S. 2012. Effect of Momordica charantia (bitter gourd) Tablets in Diabetes Mellitus: Type 1 and Type 2. Prime Res Med (PROM). 2(2): 72-74.

[25] Perumal, V., Khoo, W. C., Abdul-Hamid, A., Ismail, A., Saari, K., Murugesu, S., Abas, F., Ismail, I. S., Lajis, N. H., Mushtaq, M. Y. and Khatib, A. 2015. Evaluation of Antidiabetic Properties of Momordica charantia in Streptozotocin Induced Diabetic Rats Using Metabolomics Approach. International Food Research Journal. 22(3): 1298.

[26] Xu, X., Shan, B., Liao, C. H., Xie, J. H., Wen, P. W. and Shi, J. Y. 2015. Anti-diabetic Properties of Momordica charantia L. Polysaccharide in Alloxan-induced Diabetic Mice. International Journal of Biological Macromolecules. 81: 538-543.

[27] Chao, C.Y., Sung, P.J., Wang, W.H. and Kuo, Y.H., 2014. Anti-inflammatory effect of Momordica charantia in sepsis mice. Molecules, 19(8), pp.12777-12788.

[28] Bao, B., Chen, Y. G., Zhang, L., Xu, Y. L. N., Wang, X., Liu, J. and QU, W. 2013. Momordica charantia (Bitter Melon) Reduces Obesity-associated Macrophage and Mast Cell Infiltration as Well as Inflammatory Cytokine Expression in Adipose Tissues. PLoS One. 8(12): e84075.

[29] Yang, S. J., Choi, J. M., Park, S. E., Rhee, E. J., Lee, W. Y. Oh, K. W., Park, S. W. and Park, C. Y. 2015. Preventive Effects of Bitter Melon (Momordica charantia) against Insulin Resistance and Diabetes are Associated with the Inhibition of NF-KB and JNK Pathways in High-fat-fed OLETF Rats. The Journal of Nutritional Biochemistry. 26(3): 234-240.

[30] Chuang, C. Y., Hsu, C. Chao, C. Y., Wein, Y. S., Kuo, Y. H. and Huang, C. J. 2006. Fractionation and Identification of 9c, 11t, 13t-conjugated Linolenic Acid as an Activator of PPARa in Bitter Gourd (Momordica charantia L.). Journal of Biomedical Science. 13(6): 763-772.

[31] Kobori, M., Nakayama, H., Fukushima, K., OhnishiKameyama, M., Ono, H., Fukushima, T., Akimoto, Y.
Masumoto, S., Yukizaki, C., Hoshi, Y. and Deguchi, T. 2008. Bitter Gourd Suppresses Lipopolysaccharide-induced Inflammatory Responses. Journal of Agricultural and Food Chemistry. 56(1 1): 4004-4011.

[32] Sin, S. M., Mok, S. Y., Lee, S., Kye Man Cho, E. J. C. and Kim, H. Y. 2012. Anti-Inflammatory Effect of Bitter Melon (Momordica charantia) in RAW 264.7 Cell. Cancer Prevention Research. 17(1): 56-61.

[33] Araya, J. J., Montenegro, G., Mitscher, L. A. and Timmermann, B. N. 2010. Application of Phase-trafficking Methods to Natural Products Research. Journal of Natural Products. 73(9): 1568-1572.

[34] Nerurkar, P. V., Orias, D., Soares, N., Kumar, M. and Nerurkar, V. R. 2019. Momordica charantia (bitter melon) Modulates Adipose Tissue Inflammasome Gene Expression and Adipose-gut Inflammatory Cross Talk in High-fat Diet (HFD)-fed Mice. The Journal of Nutritional Biochemistry. 68: 16-32.

[35] Dubois, R. N., Abramson, S. B., Crofford, L., Gupta, R. A., Simon, L. S., Van De Putte, L. B. and Lipsky, P. E. 1998. Cyclooxygenase in Biology and Disease. The FASEB Journal. 12(12): 1063-1073.

[36] Lee, S. G., Kim, J. H., Son, M. J., Lee, E. J., Park, W. D., Kim J. B., Lee, S. P. and Lee, I. S. 2013. Influence of Extraction Method on Quality and Functionality of Broccoli Juice. Preventive Nutrition and Food Science. 18(2): 133.

[37] Kim, M. J., Kim, J. I. Kang, M. J., Kwon, B., Jun, J. G., Choi, J. H. and Kim, M. J. 2015. Quality Evaluation of Fresh Tomato Juices Prepared Using High-speed Centrifugal and Low-speed Masticating Household Juicers. Food Science and Biotechnology. 24(1): 61-66.

[38] Uckoo, R. M., Jayaprakasha, G. K., Balasubramaniam, V. M. and Patil, B. S. 2012. Grapefruit (Citrus paradisi Macfad) Phytochemicals Composition is Modulated by Household Processing Techniques. Journal of Food Science. 77(9): C921-C926.

[39] Perez-Cacho, P. R. and Rouseff, R. 2008. Processing and Storage Effects on Orange Juice Aroma: A Review. Journal of Agricultural and Food Chemistry. 56(21): 97859796.

[40] Ciou, S. Y., Hsu, C. C., Kuo, Y. H. and Chao, C. Y. 2014 Effect of Wild Bitter Gourd Treatment on Inflammatory Responses in BALB/c Mice with Sepsis. BioMedicine. 4(3).

[41] Bravo, L. 1998. Polyphenols: Chemistry, Dietary Sources, Metabolism, and Nutritional Significance. Nutrition Reviews. 56(11): 317-333.

[42] Pyo, Y. H., Jin, Y. J. and Hwang, J. Y. 2014. Comparison of the Effects of Blending and Juicing on the Phytochemicals Contents and Antioxidant Capacity of Typical Korean Kernel Fruit Juices. Preventive Nutrition and Food Science. 19(2): 108. 